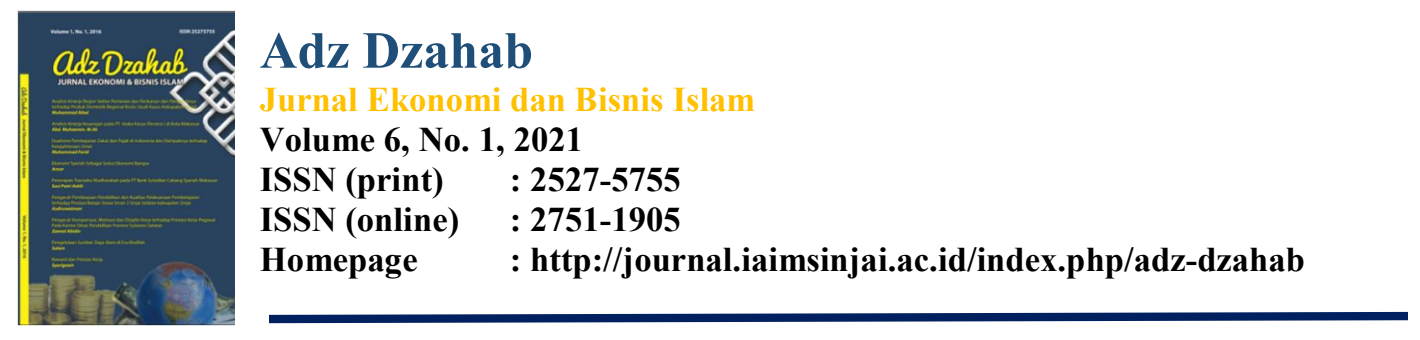

\title{
KAJIAN IMPLEMENTASI PENGELOLAAN DANA ZAKAT, INFAQ, DAN SHADAQAH DITINJAU DARI SHARIAH ENTERPRISE THEORY (WAHDAH INSPIRASI ZAKAT/WIZ KOTA MAKASSAR)
}

\author{
Ermiati $^{1}$, M. Wahyuddin Abdullah ${ }^{2}$ \\ ${ }^{1}$ (UIN) Alauddin Makassar, Gowa \\ ${ }^{2}$ (UIN) Alauddin Makassar, Gowa \\ Korespondesi Penulis. E-mail: ermiatiabdullah3@gmail.com, Tlp:085256646726
}

\begin{abstract}
Abstrak
Tujuan dari penelitian kajian implementasi pengelolaan dana zakat, infaq, dan shadaqah ditinjau dari shariah enterprise theory (Wahdah inspirasi zakat/WIZ kota Makassar) ini adalah untuk menganalisis kesesuaian antara pelaporan pengelolaan dana ZIS (zakat, infaq, dan shadaqah) yang diungkapkan oleh Lembaga wahdah inspirasi zakat (WIZ) Kota Makassar dengan menggunakan konsep Shariah Enterprise Theory. Metode yang digunakan pada artikel kajian implementasi pengelolaan dana zakat, infaq, dan shadaqah ditinjau dari shariah enterprise theory (Wahdah inspirasi zakat/WIZ kota Makassar) ini adalah telaah kritis dengan melakukan penilaian secara sistematis suatu artikel atau hasil penelitian terhadap pengelolaan dana ZIS pada Lazis Wahdah kota Makassar. Hasil analisis penelitian kajian implementasi pengelolaan dana zakat, infaq, dan shadaqah ditinjau dari shariah enterprise theory (Wahdah inspirasi zakat/WIZ kota Makassar) ini menunjukkan bahwa pelaporan dana ZIS yang dilakukan oleh Lazis Wahdah kota Makassar kota sebagian sudah sesuai dengan konsep SET, yaitu aspek pada Allah SWT, aspek direct stakeholders, dan indirect stakeholder serta terdapat kekurangan pada aspek kontribusi pada alam.
\end{abstract}

Kata Kunci: Zakat, Infaq, Shadaqah, dan Shariah Enterprise Theory

\section{Pendahuluan}

Indonesia merupakan salah satu negara besar dalam hal jumlah penduduknya, bahkan Indonesia menempati urutan ke-empat setelah Cina, India, dan Amerika. Pada tahun 2016, menurut data pada Badan Pusat Statistik (BPS), jumlah penduduk Indonesia mencapai 257.912.349 jiwa (www.bps.go.id). Dengan jumlah penduduk yang besar tersebut Indonesia tentunya memiliki berbagai permasalahan, salah satunya adalah permasalahan dalam bidang ekonomi.

Terdapat dua Permasalahan yang umumnya dihadapi oleh negara-negera berkembang termasuk Indonesia dalam bidang ekonomi, yaitu kesenjangan ekonomi atau ketimpangan dalam distribusi pandapatan antara kelompok masyarakat berpendapatan tinggi dan kelompok masyarakat berpendapatan rendah serta tingkat kemiskinan atau jumlah orang berada di bawah garis kemiskinan (poverty line) (Tulus, 2001: 9). Tingkat kemiskinan di Indonesia pada tahun 2018 tercatat sebanyak 26,58 juta(penduduk dengan pengeluaran per kapita per bulan di bawah garis kemiskinan). Jumlah kemiskinan erat kaitannya dengan meningkatnya pengangguran di Indonesia, tidak bisa dipungkiri karena susahnya mencari pekerjaan, persaingan dimana-mana.

Kesejahteraan bangsa, dinamika intelektual rakyatnya dengan banyaknya asumsi dalam penanggulangan masalah sosial-ekonomi, menjadi bahan kajian yang menarik di ranah akademik. Dalam konteks mendorong pencapaian prioritas nasional dalam 


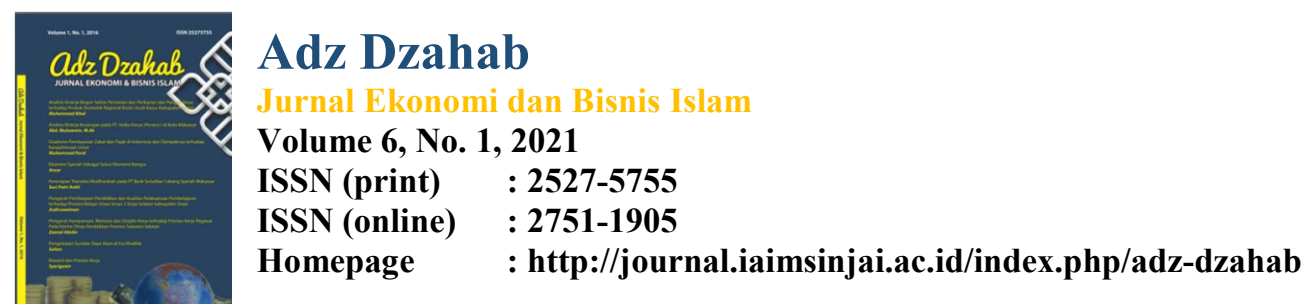

pengentasan kemiskinan, instrumen ZIS (Zakat, Infaq, dan Shadaqah) hadir dengan pendekatan holistik dengan bantuan sosial, pemberdayaan masyarakat, dan meningkatkan mata pencaharian. Multifiah mengatakan bahwa ZIS digunakan memberi mereka(mustahik) peluang kerja berupa bantuan modal/peralatan kerja, bantuan pendidikan, bantuan fasilitas kesehatan, dan sebagainya, sehingga nantinya mereka lebih produktif (Multifiah, 2011: 6). Perlu diketahui bahwa pengumpulan zakat belum maksimal di negara kita. Potensi dana zakat yang mestinya terkumpulkan tidak sebanding dengan hasil yang didapatkan, menurut penelitian IPB dan BAZNAS mencapai Rp 217 Triliun (Indonesia Zakat dan Development Report 2012), (IMZ 2013). Sedangkan yang terhimpun sampai saat ini baru sekitar Rp 6,2 Triliun atau 2\% dari potensi yang ada (BAZNAS, 2018: 3).

Realisasi penerimaan zakat yang masih rendah dibandingkan potensinya, serta masih terkonsentrasi pada satu jenis zakat fitrah, menurut Mufraini mengemukakan bahwa terdapat permasalahan-permasalahan yang menyebabkan seorang muslim yang telah mempunyai harta yang cukup untuk wajib zakat tidak patuh atau tidak sadar untuk mengeluarkan zakat dari hartanya (BASZNAS, 2017: 1). Salah satu kemungkinan utama adanya ketimpangan tersebut adalah realitas bahwa masih banyak muzaki di Indonesia yang membayarkan zakatnya tanpa melalui lembaga zakat, namun langsung kepada mustahiq sehingga hal tersebut menyebabkan pembayaran data dari muzaki tidak terdata oleh pengelola zakat (Uzaifah, 2007: 127-143). Rendahnya kepercayaan masyarakat terhadap lembaga pengelola zakat juga dapat menjadi penyebab kesenjangan antara besaran potensi zakat dan nominal zakat yang diterima. Profesionalisme lembaga zakat dan hasil pengelolaan zakat yang tidak terpublikasi kepada masyarakat luas adalah hal yang membuat kepercayaan masyarakat rendah terhadap lembaga pengelola zakat (Hafiduddin, 2006: 100-109). Olehnya itu, kemauan dan kepatuhan masyarakat dalam membayar zakat berbanding lurus dengan peran dari badan atau lembaga pengelola zakat.

Membangun kepercayaan kepada masyarakat sejatinya sesuatu yang lazim bagi setiap entitas syariah karena hal demikian merupakan bentuk pelaporan dan tanggungjawab kepada masyarakat. Selain bentuk tanggungjawab kepada masyarakat (horizontal), tanggungjawab kepada Allah (vertikal) adalah yang lebih utama. Bentuk pertanggungjawaban seperti ini terkadang dilupakan oleh entitas syariah, sehingga banyak yang mengacu pada laba semata dan dilaporkan dalam bentuk laporan keuangan konvensional yang didasarkan pada Proprietary dan Entity Theory dengan ultimate goal adalah laba. Jika Proprietary Theory dan Entity Theory diangggap kurang sesuai dengan tujuan yang dimiliki oleh bisnis Islam, maka yang dianggap mewakili adalah Enterprise Theory karena dalam teori ini suatu entitas tidak hanya berfokus pada laba tapi juga pada stakeholder. Namun Enterprise Theory juga dianggap belum dapat menampung aspek pertanggungjawaban dan ketundukan terhadap syariah. Akhirnya Shariah Enterprise Theory (SET) dianggap lebih dapat mewakili dan dikembangkan pula berdasarkan metafora zakat yang pada dasarnya memiliki karakter keseimbangan (Iwan, 2001: 131145).

Realitanya, entitas pada umumnya berorientasi pada profit dengan menggunakan teori entitas. Teori entitas memiliki nilai individual yang bermakna bahwa hanya mengedepankan karakter egoistik, sehingga nilai altruistik (sosial) akan terabaikan. Tetapi dengan SET, khususnya bagi perusahaan yang berbasis nilai syariah, dapat menggunakan konsep orientasi zakat yang berarti bahwa perusahaan akan berusaha untuk mencapai realisasi zakat yang optimum, ini berarti Net Profit bukan lagi ukuran keberhasilan manajemen perusahaan, tetapi sebaliknya zakat menjadi ukuran kinerja materi dan spiritual (Sigit, 2016: 12-24). 


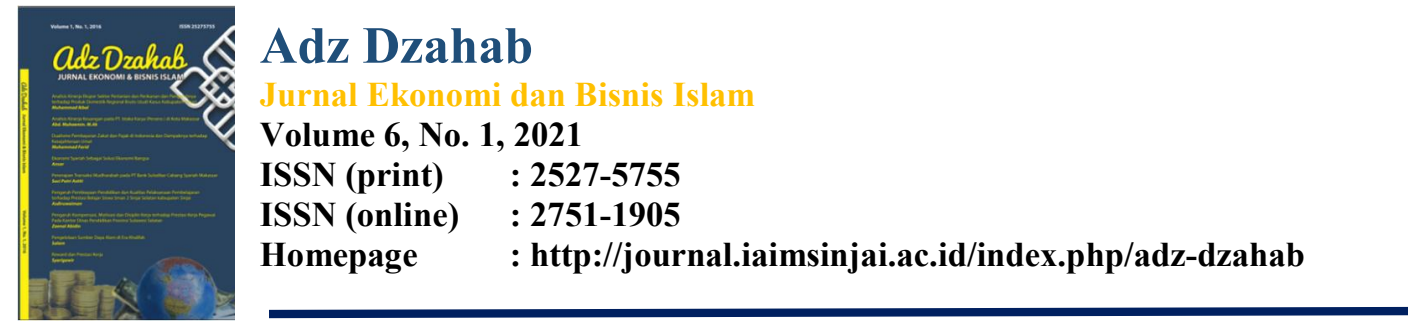

Berdasarkan hasil penelusuran peneliti, menyimpulkan bahwa minimnya penelitian yang membahas tentang ZIS dalam tinjauan SET. Penelitian-penelitian yang ada kebanyakan menyinggung pengelolaan corporate social responsibility (CSR) yang dilakukan oleh entitas syariah dikaitkan dengan perspektif SET, seperti penelitian Rahmah (2018) tentang akuntabilitas SET pada lembaga bisnis syariah. Penelitian ini menyimpulkan bahwa dengan SET akan memberikan tujuan bahwa hidup di dunia adalah rahmatan lil alamin yang mengharuskan umat muslim memberikan manfaat kepada sesama sebagai makhluk Allah (Rahmah, 2018: 1-12)

Perwujudan konsep SET dilakukan dengan pemisahan pertanggungjawaban dana bisnis dan dana sosial yang dikelola oleh pihak perusahaan. Pertanggungjawaban dana bisnis yang dikelola pihak perusahaan dipertanggungjawabkan kepada Allah melalui dana zakat dan laporan pertanggungjawabannya dibuat oleh pemilik sebagai bahan evaluasi peningkatan target zakat kedepan. Dana non bisnis yang dikelola pihak perusahaan dipertanggungjawabkan kepada masyarakat melalui berbagai kegiatan sosial kemanusiaan dan laporan pertanggungjawabannya diberikan kepada masyarakat melalui berbagai media seperti poster dan spanduk.

Konsep SET diterapkan dengan tujuan dapat memberikan dasar dalam pembuatan pelaporan yang berasaskan pada kepentingan stakeholders dibanding pada kepentingan stokhoders. Dengan demikian, pelaporan dana ZIS merupakan praktik yang dibentuk dengan berdasar pada nilai etika dan norma yang tidak lepas dari nilai-nilai agama Islam atau nilai-nilai syariah.

Berdasarkan atas dasar argumen dan hasil penelitian diatas, peneliti ingin mengungkapkan analisis kualitatif terhadap penggunaan dana ZIS (Zakat, Infaq, dan Shadaqah) pada organisasi pengelola ZIS atau LAZ/BAZ dalam prespektif konsep Shariah Enterprise Theory. Sehingga dapat ditelusuri lebih dalam, bagaimana impelmentasi dana ZIS kepada Stakeholders jika menggunakan prespektif Shariah Enterprise Theory pada Lazis Wahdah kota Makassar. Dengan demikian tujuan penelitian ini adalah untuk menganalisis kesesuaian antara informasi pelaporan dana Zakat, Infaq, dan Shadaqah (ZIS) yang diungkap Lazis Wahdah kota Makassar dengan konsep Shariah Enterprise Theory (SET).

\section{Metode}

Metode yang digunakan dalam tulisan ini adalah telaah kritis. Telaah kritis adalah penilaian secara sistematis suatu masalah atau hasil penelitian tentang relevansi, validitas dan pentingnya hasil penelitian dalam konteks tertentu. Dalam artikel ini, penulis mencoba menelaah konsep shariah enterprise theory dalam penerepannya terhadap pengelolaan dana zakat, infaq, dan shadaqah pada Lazis Wahdah kota Makassar insprisi zakat/WIZ kota makassar.

\section{Hasil dan Pembahasan}

Lembaga zakat merupakan badan yang mengelola sumber dana baik perorangan maupun badan usaha dimana penerimaan zakat tersebut sesuai dengan kaidah Islam yang berlaku atau amil yang menerima zakat baik zakat fitrah maupun zakat harta atau zakat dalam bentuk lainnya (infaq dan shadaqah). Lazis Wahdah kota Makassar kota Makassar adalah salah satu lembaga yang bergerak dalam penghimpunan dana zakat, infaq, dan shadaqah dan akan di distribusikan ke 8 asnaf jika dananya berasal dari zakat dan kepada orang-orang yang membutuhkan.

Dana yang dihimpun dari Lazis Wahdah kota Makassar kota Makassar dan didistribusikan dalam bentuk program yang dibagi menjadi lima berkah dengan berbagai 


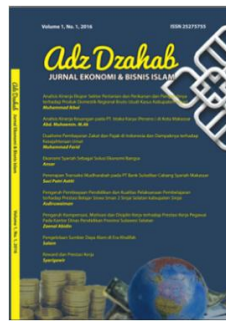

Adz Dzahab

Jurnal Ekonomi dan Bisnis Islam

Volume 6, No. 1, 2021

ISSN (print) : 2527-5755

ISSN (online) : 2751-1905

Homepage : http://journal.iaimsinjai.ac.id/index.php/adz-dzahab

program di dalamnya diantaranya berkah hidayah, berkah mandiri, berkah juara, berkah sehat, dan berkah peduli. Adapun penjabaran programnya sebagai berikut:

1. Berkah Hidayah
a. DaiQu (Da'i Qur'ani)
b. Tebar Al Qur'an Nusantara
c. RumahQu (Rumah Qur'ani)
d. Berbagi Bersama Muallaf
e. Tahfizh Community

2. Berkah Juara
a. Beasiswa Dai
b. Sekolah Guru Tahfidz
c. IBES (Islamic Boarding Enterpreneur School)
d. BEST (Beasiswa Santri Tahfidz)
e. Berarti (Beasiswa Berprestasi)
f. TAS (Tebar Alat Sekolah)

3. Berkah Mandiri
a. Perintis (Pelatihan Keterampilan dan Bisnis)

b. Bina Usaha Mikro Nusantara

4. Berkah Sehat
a. Berkemas (Berkah Kesehatan Masyarakat)
b. Klinik Sehat
c. Ambulance Gratis
d. Khitanan Massal

5. Berkah Peduli
a. Bersatu (Berkah Santunan Dhuafa)
b. Peduli Lingkungan
c. Peduli Kemanusiaan

Program ini bertujuan, untuk menjawab keresahan masyarakat pra sejahtera dan masyarakat luas. Implementasi dari program-program di atas dapat dilihat pada pelaporan dana ZIS Lazis Wahdah kota Makassar kota Makassar pada bulan januari 2018 di bawah ini:

\begin{tabular}{|c|c|c|c|}
\hline $\begin{array}{l}\text { A. Laporan Perubahan Dana } \\
\text { Zakat }\end{array}$ & & \multicolumn{2}{|c|}{ b. laporan perubahan dana infaq } \\
\hline PENERIMAAN & & PENERIMAAN & \\
\hline Zakat muzakki personal & $468,895,000.00$ & penerimaan infaq terikat & $777,694,716.00$ \\
\hline zakat perusahaan & - & $\begin{array}{l}\text { penerimaan infaq tidak } \\
\text { terikat personal }\end{array}$ & $1,738,246,500.00$ \\
\hline & $468,895,000.00$ & & $2,515,941,216.00$ \\
\hline PENGGUNAAN & & PENGGUNAAN & \\
\hline Penyaluran untuk asnaf fakir & $423,229,000.00$ & $\begin{array}{l}\text { biaya program berbagi } \\
\text { hidayah }\end{array}$ & $655,490,500.00$ \\
\hline Penyaluran untuk asnaf miskin & $2,500,000.00$ & $\begin{array}{l}\text { biaya program berbagi } \\
\text { sesama }\end{array}$ & $983,165,450.00$ \\
\hline penyaluran untuk asnaf riqab & (5) & $\begin{array}{l}\text { biaya program berbagi } \\
\text { sehat }\end{array}$ & $44,225,000.00$ \\
\hline penyaluran untuk asnaf gharim & & biaya program berbagi & \\
\hline
\end{tabular}




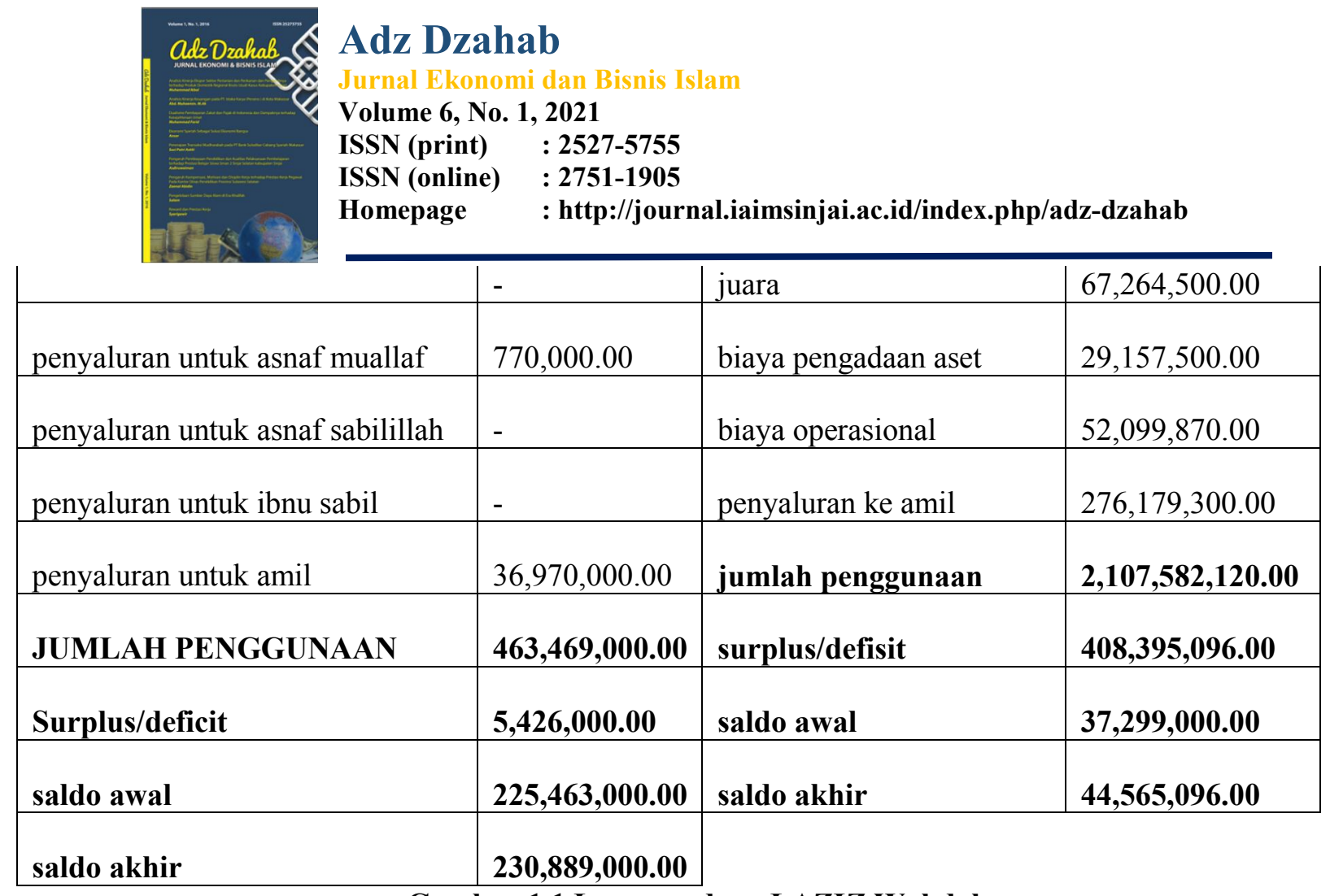

Gambar 1.1 Laporan dana LAZIZ Wahdah

Dari data tersebut penggunaan dana zakat yang diperoleh oleh oleh Lazis Wahdah kota Makassar kota Makassar sebanyak Rp. 468.895.000,- dan untuk penggunaan dana zakat

khususnya penyaluran Asnaf Fakir sebanyak Rp. 423.449.000,-. Penyaluran dana zakat untuk asnaf fakir sudah termasuk dalam penggunaan dana konsumtif dan produktif yang diberikan.

Pengalokasian dana infaq tersalurkan secara merata dibeberapa program berkah dengan jumlah penggunaan Rp. 2.107.582.120. Hal ini, menandakan bahwa pelaksanaan dan pengalokasian dana ZIS menunjukkan transparansi dan disalurkan secara amanah dan propesional.

\section{Tinjauan Pelaporan Dana ZIS oleh Lazis Wahdah kota Makassar kota Makassar Perspektif Konsep Shariah Enterprise Theory}

Entitas bisnis yang berorientasi pada profit dan stockholders merupakan implikasi dari penggunaan entity theory. Triyuwono (2001: 131-145) mengatakan bahwa entitas dengan menggunakan metafora zakat atau orientasinya pada zakat tidak kmpatibel menggunakan entity theory, karena entity theory tidak lepas dari nilai individual sedangkan metafora zakat memiliki nilai sosial. Secara prinsip pertanggungjawaban maka ada tiga konsep yang bisa digunakan, antara lain proprietary theory, entity theory, dan enterprise theory. Enterprise theory (ET) lebih mencakup pada aspek sosial dan pertanggungjawaban. Konsep ini bertujuan bukan hanya sekedar memberikan pelayanan bagi pemilik perusahaan, melainkan juga kepada masyarakat. Sigit dan Restu mengatakan bahwa ET lebih cenderung ke arah nila-nilai kapitalisme. Oleh karena itu, ET dikembangkan agar lebih dekat dengan syariah sehingga pada akhirnya diperoleh konsep yang dikenal dengan Syariah Enterprise Theory (SET) yang dikembangkan oleh Iwan Triyuwono (Sigit Hermawan, dkk, 2016:12-24)

Sesuai dengan konsep SET yang membagi laporan penggunaan dana ZIS ke dalam empat aspek, yakni kontribusi vertikal kepada Allah SWT, kontribusi horizontal direct stakeholders, kontribusi horizontal in direct stakeholders, dan kontibusi horizontal kepada alam. Berikut penjelasannya. 


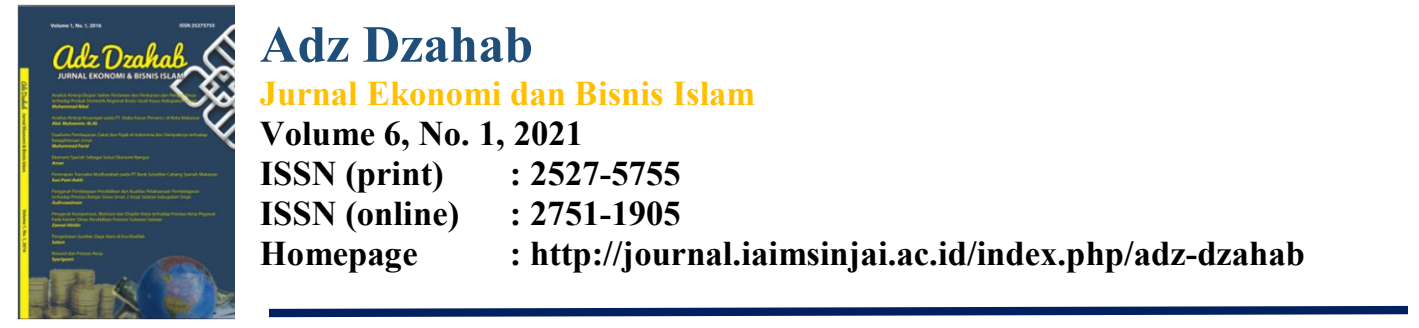

1. Kontribusi Vertikal : Allah SWT

Pada Laporan Penggunaan Dana ZIS Lazis Wahdah kota Makassar kota Makassar bulan Januari 2018, telah tertera adanya bantuan dalam bentuk keagamaan berupa program berbagi hidayah dengan berbagai program-program yang dijalankan. Dapat dilihat pada pelaporannya bahwa penggunaan dana pada program ini sejumlah Rp. 655.490.500. Dengan angka yang lumayan besar menunjukkan bahwa pengembangan kualitas umat dan ekspansi dakwa memiliki prioritas utama pada lembaga ini, meskipun pada laporan keuangan yang disajikan tidak menggambarakan secara detail programprogram yang dijalankan.

Dari pelaporan di atas, dapat disimpulkan bahwa amanah dari Allah dilaksanakan sebenar-benarnya melalui tebar hidayah yang sejatinya merupakan perintah dan tanggungjawab seorang muslim untuk senantiasa mengajak saudaranya dalam kebaikan. Sebagaimana diungkapkan oleh omi dan nur bahwa sesuatu yang dimiliki oleh para stakeholder adalah amanah dari Allah sehingga stakeholder bertanggungjawab untuk menggunakannya dengan cara dan tujuan yang telah ditetapkan oleh Allah untuk mendapatkan ridha-Nya dengan menjadikan amanah tersebut membawa rahmat bagi seluruh alam (Omi, 2018: 169-182).

2. Kontribusi Horizontal : Direct Stakeholders

Pada Laporan Penggunaan Dana ZIS Lazis Wahdah kota Makassar kota Makassar bulan Januari 2018, berkaitan dengan kontribusi terhadap nasabah atau donatur LAZ memberikan perhatian yang cukup besar, karena salah satu dari nilai-nilai dasar yang diterapkan Lazis Wahdah kota Makassar kota Makassar adalah fokus pada donatur atau nasabah. Hal ini ditunjukkan dengan kinerja keuangan yang transparansi pada Lazis Wahdah kota Makassar kota Makassar. Dari hal ini banyak para pihak yang merasa puas dan jelas akan suatu pelaporan dana ZIS yang dimiliki oleh Lazis Wahdah kota Makassar kota Makassar. Dengan bukti penerimaan baik dari zakat, infaq maupun shadaqah.

3. Kontribusi Horizontal : Indirect Stakeholders

Pada Laporan Penggunaan Dana ZIS Lazis Wahdah kota Makassar kota Makassar bulan Januari 2018, kepedulian Lazis Wahdah kota Makassar kota Makassar terhadap peningkatan kualitas hidup masyarakat baik dalam bidang pendidikan dan kesehatan dapat dilihat dari program rutinitas dana zakat yang disalurkan, melalui program tersebut Lazis Wahdah kota Makassar kota Makassar memberikan bantuan yang bertujuan untuk menciptakan kesejahteraan dalam jangka panjang yakni bisa berupa bantuan biaya pendidikan dengan jumlah pengeluaran Rp. 67.264.500,. Adapun untuk kesehatan berjumlah Rp. 44.500.000, beserta dengan penggunaan dana zakat dengan penggunaan berjumlah Rp. 463.469.000. Bantuan tersebut tersalurkan dalam program berkah juara dan berkah sehat serta berkah peduli.

Kepedulian terhadap sesama akan memberikan dampak terhadap stakeholder, seperti yang diungkapkan Elvyra bahwa ada dua yang akan bertambah:

a. Mental value added (nilai tambah mental) adalah tambahan nilai berupa rasa altruistik, rasa senang, dan rasa persaudaraan.

b. Spiritual value added (nilai tambah spiritual) adalah tambahan nilai berupa rasa ikhlas dan rasa kehadiran ketuhanan (Elvira, 2013: 195-215).

Nilai tambah mental dan spiritual sudah seharusnya melekat pada lembagalembaga pengelola dana ZIS karena tugas dan fungsinya untuk mensejahterahkan umat yang memiliki ketidak mampuan dalam memenuhi kebutuhan hidupnya.

Nilai tambah mental dan spiritual sudah seharusnya melekat pada lembagalembaga pengelola dana ZIS karena tugas dan fungsinya untuk mensejahterahkan umat yang memiliki ketidak mampuan dalam memenuhi kebutuhan hidupnya. 


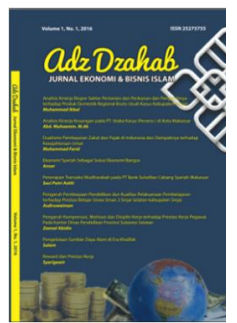

Adz Dzahab

Jurnal Ekonomi dan Bisnis Islam

Volume 6, No. 1, 2021

ISSN (print) : 2527-5755

ISSN (online) : 2751-1905

Homepage : http://journal.iaimsinjai.ac.id/index.php/adz-dzahab

4. Kontribusi Horizontal : Alam

Pada Laporan Penggunaan Dana ZIS Lazis Wahdah kota Makassar kota Makassar bulan Januari 2018, Lazis Wahdah kota Makassar kota Makassar tidak menunjukkan kontribusi kepada alam. Kendatipun demikian, Lazis Wahdah kota Makassar kota Makassar tetap mengakui dengan adanya program peduli lingkungan. Begitu pula menurut SET, alam adalah salah satu stakeholders yang harus mendapat perhatian dan memiliki hak untuk mendapatkan kesejahteraan. Namun perhatian Lazis Wahdah kota Makassar kota Makassar terhadap alam masih belum terbentuk dengan baik.

Dengan demikian berdasarkan data pengelolaan dana ZIS Lazis Wahdah kota Makassar kota Makassar, maka dapat digambarkan pelaporannya berdasarkan perspektif SET, sebagai berikut:

\begin{tabular}{|c|c|c|c|}
\hline No. & Keterangan Pengeluaran & \multicolumn{2}{|c|}{ Nilai Nominal } \\
\hline 1 & $\begin{array}{l}\text { Kontribusi kepada Allah SWT } \\
\text { a. Partisipasi pembuatan masjid/mushollah } \\
\text { b. Sosialisasi tenaga dakwah sosial (Berkah } \\
\text { Hidayah) }\end{array}$ & $\begin{array}{l}\text { Rp. } \\
\text { Rp. }\end{array}$ & $\begin{array}{r}\text { xxx,- } \\
655.490 .500\end{array}$ \\
\hline 2 & $\begin{array}{l}\text { Kontribusi kepada Direct Stakeholders } \\
\text { a. Biaya cetak majallah } \\
\text { b. Biaya program kesehatan karyawan } \\
\text { c. Biaya program pelatihan karyawan } \\
\text { d. Biaya program jenjang karir karyawan }\end{array}$ & $\begin{array}{l}\text { Rp. } \\
\text { Rp. } \\
\text { Rp. } \\
\text { Rp. }\end{array}$ & $\begin{array}{l}\mathrm{xxx},- \\
\mathrm{xxx},- \\
\mathrm{xxx},- \\
\mathrm{xxx},-\end{array}$ \\
\hline 3 & $\begin{array}{l}\text { Kontribusi kepada Indirect Stakeholders } \\
\text { a. Biaya pendidikan (Berkah Juara) } \\
\text { b. Biaya hidup (Zakat) } \\
\text { c. Biaya kesehatan (Berkah Sehat) } \\
\text { d. Biaya program pemberdayaan ekonomi } \\
\text { e. Biaya partisipasi khitanan massal }\end{array}$ & $\begin{array}{l}\text { Rp. } \\
\text { Rp. } \\
\text { Rp. } \\
\text { Rp. } \\
\text { Rp. }\end{array}$ & $\begin{array}{r}67.264 .500 \\
463.469 .000 \\
44.225 .000 \\
\mathrm{xxx},-- \\
\mathrm{xxx},-\end{array}$ \\
\hline 4 & $\begin{array}{l}\text { Kontribusi kepada alam } \\
\text { a. Partisipasi program penghijauan lingkungan } \\
\text { b. Partisipasi program pencegahan pencemaran } \\
\text { lingkungan } \\
\text { c. Partisipasi program jumat bersih }\end{array}$ & $\begin{array}{l}\text { Rp. } \\
\text { Rp. } \\
\text { Rp. }\end{array}$ & $\begin{array}{l}\mathrm{xxx},- \\
\mathrm{xxx},- \\
\mathrm{xxx},-\end{array}$ \\
\hline
\end{tabular}




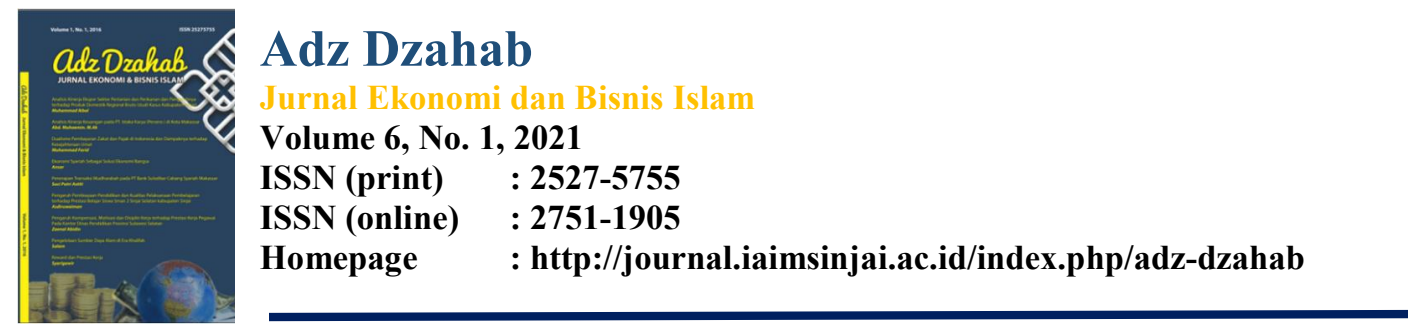

Berdasarkan data-data yang sudah dijelaskan dan juga berdasarkan analisis kesesuaian data dengan konsep SET dapat dijelaskan sebagai berikut (Meutia, 2010) :

1. Pengungkapan pelaporan sosial diatas juga sudah mencerminkan tujuan utama yakni akuntabilitas manusia terhadap tuhan. Karena LAZIS Wahdah dibentuk untuk mengelola zakat, infaq dan shadaqah yang akuntabilitas, amanah, dan propesional. Seperti halnya manusia yang dibebankan tanggungjawab di muka bumi ini untuk menjaga dan memanfaatkan sumberdaya dalam rangka untuk mendistribusikan pada seluruh makhluk bumi secara adil.

2. Pengungkapan pelaporan sosial tersebut juga sudah memberikan sarana informasi kepada seluruh stakeholders mengenai seberapa jauh pelaksanaan, pengelolaan, dan pendistribusian dana ZIS yang telah dikelola oleh organisasi LAZIS Wahdah dengan melampirkan dan membagikan laporan keuangan dana ZIS tersebut dengan melalui sarana media cetak yakni majalah yang disebar kepada seluruh donatur dan masyarakat sehingga para donatur dan masyarakat bisa lebih leluasa dalam memantau perkembangan pengelolaan dan ZIS.

3. Pengungkapan pelaporan sosial tersebut sudah memberikan informasi berbentuk material dan spiritual dalam bentuk pemisahan pengeluaran internal organisasi dan kepentingan umum masyarakat. Dan pelaporan tersebut sudah menunjukkan pengungkapan informasi secara menyeluruh secara kuantitatif tentang penjelasan tambahan mengenai keterangan pihak- pihak yang telah menerima langsung bantuan dari pembagian zakat, infaq dan shadaqah yang ditampilkan dalam pelaporan tersebut.

Dilihat dari program kerja yang tergambarkan menunjukkan bahwa penerapan shariah enterprise theory sangat direkomendasikan untuk diterapkan pada lembagalembaga penghimpun dana zakat, infaq, dan shadaqah. Disamping penyalurannya kepada 8 asnaf (golongan), ternyata tidak lepas dari program-program yang bersentuhan dengan dakwah bahkan alam pun menjadi sasaran program meskipun dalam pelaporan dananya tidak tergambarakan.

\section{Simpulan}

Kesimpulan penelitian ini adalah bahwa dengan mengunakan konsep shariah enterprise theory pada entitas syariah maka sangat diharapkan mampu mengelola dana umat secara amanah, transparan, dan profesional. Untuk pelaporan dana ZIS yang dilakukan oleh Lazis Wahdah kota Makassar kota Makassar sebagian sudah sesuai dengan konsep SET, yaitu aspek pada Allah SWT berupa pembiayaan dakwah sosial. Aspek direct stakeholders untuk kontribusi kepada donatur berupa transparansi kinerja keuangan yang dilakukan secara terbuka melalui cetak majalah, aspek indirect stakeholders berupa pembiayaan pendidikan, kesehatan, biaya hidup serta bantuan lainnya kepada masyarakat kurang mampu. Namun terdapat kekurangan yaitu belum terbentuknya program bagian kontribusi terhadap kepedulian lingkungan sekitar atau alam dan untuk kontribusi kepada amil Lazis Wahdah kota Makassar kota Makassar belum memiliki bentuk pengeluaran tunjangan untuk karyawan. 


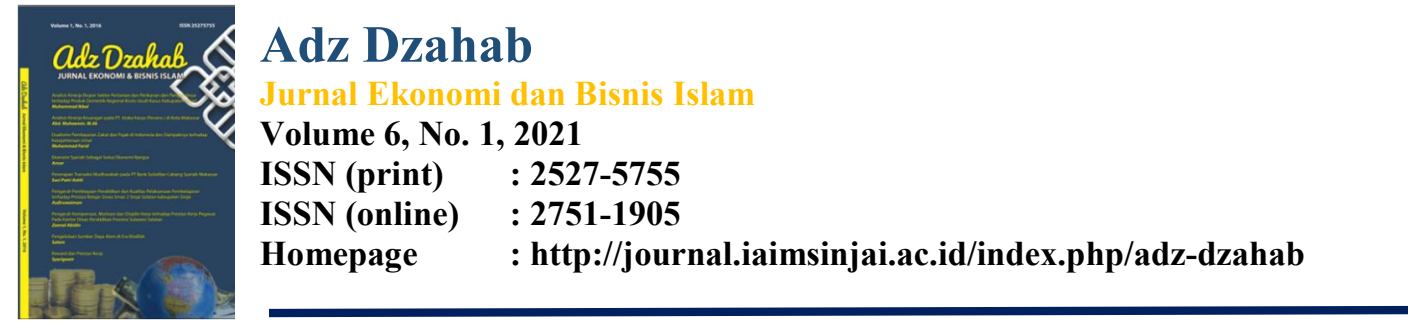

\section{Daftar Pustaka}

BAZNAS. 2018. Statistik Zakat Nasional 2017. Jakarta: Liaison dan Pelaporan

Busyrah. 2016. Faktor-Faktor Penyebab Kurangnya Minat Masyarakat Membayar Zakat (Studi Kasus Desas Parappe Kec. Campalagian Kab. Polewali Mandar). J-ALIF Jurnal Penelitian Hukum Ekonomi Syariah dan Sosial Budaya Islam 1, No. 1

Fatmawati dan Natsir, Sukriah. 2017. Refleksi Realitas "Sustainability" dalam Praktik Sustainability Reporting: Perspektif Shariah Enterprise Theory. Prosiding Seminar Hasil Penelitian

Hafidhuddin. 2011. Peran Strategis Organisasi Zakat dalam Menguatkan Zakat di Dunia. Jurnal Al-Infaq 2, No. 1

Hafiduddin. 2006. Analisis Efektifitas Promosi Lembaga Amil Zakat Dalam Penghimpunan Zakat Bagi Peningkatan Kesejahteraan Keluarga Dhuafa: Studi Kasus Lembaga Amil Zakat Dompet Dhuafa Republika. Media Gizi \& Keluarga 30, No. 1

Hermawan, Sigit dan Rini, Restu Widya. 2016. Pengelolaan Dana Zakat, Infaq, dam Shadaqah Perspektif Shariah Enterprise Theory. Riset Akuntansi dan Keuangan Indonesia 1, No. 1

Kalbarini, Rahmah Yulisa dan Suprayogi Noven. 2014. Implementasi Akuntabilitas dalam Konsep Metafora Amanah di Lembaga Bisnis Syariah (Studi Kasus: Swalayan Pamella Yogyakarta). JESTT 1, No. 7

Kalbarini, Rahmah Yulisa. 2018. Implementasi Akuntabilitas dalam Shariah Enterprise Theory di Lembaga Bisnis Syariah (Studi Kasus: Swalayan Pamella Yogyakarta). Al-Tijary 4, No. 1

Mansur, Syuhada. 2012. Pelaporan Corporate Social Responsibility Perbankan Syariah dalam Perspektif Syariah Enterprise Theory. Economic: Jurnal Ekonomi dan Hukum Islam 2, No. 2

Meutia, I. 2010. Shariah Enterprise Theory Sebagai Dasar Pengungkapan Tanggungjawab Sosial Untuk Bank Syariah. Disertasi. Program Pascasarjana. Malang: Universitas Brawijaya..

Multifiah. 2011. ZIS untuk Kesejahteraan. Malang: UB Press

Mursyid. 2006. Mekanisme Pengumpulan Zakat, Infaq, dan Shadaqah: Menurut Hukum Syara' dan Undang-Undang. Yogyakarta: Magister Insania Press

Nasution, Abdul Haris, et.al., Kajian Strategi Zakat, Infaq dan Shadaqah dalam Pemberdayaan Umat. Jurnal Ekonomi Bisnis Syariah 1, No. 1

Novarela, Dori dan Sari, Indah Mulia. 2015. Pelaporan Corporate Social Responsibility Perbankan Syariah dalam Perspektif Syariah Enterprise Theory. Jurnal Akuntansi dan Keuangan Islam 2, No. 2

Priyono, Sugeng. 2013. Zakat sebagai Instrumen dalam Kebijakan Fiskal. Al Mashlahah Jurnal Hukum dan Pranata Sosial Islam 1, No. 2

Samsiyah dkk, 2013. Kajian Implementasi Corporate Social Responsibility Perbankan Syariah Ditinjau dari Shariah Enterprise Theory pada PT. Bank Pembiayaan Rakyat Syariah Bhakti Sumekar Cabang Pamekasan. Jurnal InFestasi 9, No. 1

Tabik, Ahmad. 2015. Manajemen Pengelolaan Zakat yang Efektif di Era Kontemporer. Ziswaf 2, No. 1

Tambunan Tulus. 2001. Perekonomian Indonesia: Teori dan Temuan Empiris. Jakarta: Ghalia Indonesia

Triyuwono, Iwan. 2001. Metafora Zakat dan Shariah Enterprise Theory sebagai Konsep Dasar dalam Membentuk Akuntansi Syariah. JAAI 5, No. 2 


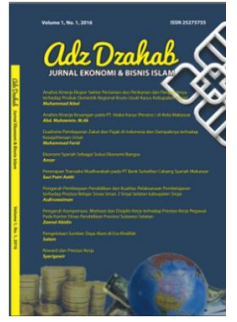

Adz Dzahab

Jurnal Ekonomi dan Bisnis Islam

Volume 6, No. 1, 2021

ISSN (print) : 2527-5755

ISSN (online) : 2751-1905

Homepage : http://journal.iaimsinjai.ac.id/index.php/adz-dzahab

Uzaifah. 2007. Studi Deskriptif Prilaku Dosen Perguruan Tinggi Islam DIY Dalam Membayar Zakat. La Riba Jurnal Ekonomi Islam 1, No. 1

Wulandari, Anis dkk. 2011. Telaah Kritis Atas Konsep Good Corporate Governance Ditinjau dari Shariah Enterprise Theory. Jurnal Ekonomi \& Keuangan Islam 1, No. 2

www.bps.go.id. Diakses pada tanggal 25 Mei 2021

Yaya, Rizal, Et.al. 2009. Akuntansi Perbankan Syariah: Teori dan Praktek Kontemporer. Jakarta: Salemba Empat.

Pramiana, Omi dan Anisah, Nur. 2018. Implementasi Corporate Social Responsibility (CSR) dalam Perspektif Shariah Enterprise Theory. EKSIS 13, No. 2

Soedarso, Elvyra Handayani. 2013. Penilaian Kinerja Fisik (Materi) Koperasi Syariah Menurut Perspektif Shariah Enterprise Theory Dengan Nilai Tambah Syariah dan Zakat Sebagai Indikator. Jurnal Riset Akuntansi dan Keuangan 1, No. 3

Septian, Krisno dan Julianto, Wisnu. 2018. Pengembangan Indeks Pengungkapan dengan Maqhasid Syariah dalam Memunculkan Indirect Stakeholders yang Terlupakan. Jurnal Nisbah 4, No. 2

Uyun, Qurratul. 2015. Zakat, Infaq, Shadaqah, dan Wakaf sebagai Konfigurasi Filantropi Islam. Islamuna 2, No. 2 